\title{
PENGEMBANGAN MODEL ASESMEN OTENTIK DALAM PEMBELAJARAN KETERAMPILAN BERBAHASA INDONESIA LISAN DI SEKOLAH MENENGAH ATAS (SMA)
}

\author{
Sri Wahyuni \\ Fakultas Keguruan dan Ilmu Pendidikan Universitas Islam Malang \\ e-mail: sriwy@yahoo.co.id
}

\begin{abstract}
This study aims to develop a model of authentic assessment in the learning of the spoken Indonesian language skill in senior high schools. The model was adapted from the Reflective, Recursive Design and Development (R2D2) model by Willis and the model of spoken language assessment by O'Malley \& Pierce. The product of the development is a set of authentic assessment in the spoken Indonesian language skill in senior high schools, consisting of (a) assessment planning, (b) assessment mapping, (c) assessment instrument and rubric, (d) evaluation standard, and (e) score interpretation. The product is equipped with a VCD containing the implementation model to help teachers conduct authentic assessment. In general, the developed authentic assessment model is effective to evaluate the spoken Indonesian language skill in senior high schools.
\end{abstract}

Keywords: assessment model, authentic assessment, spoken Indonesian language skill

\section{PENDAHULUAN}

Asesmen otentik dikembangkan dalam penelitian ini karena memiliki banyak kelebihan dibandingkan dengan penilaian konvensional. Penilaian konvensional hanya menekankan tagihan penguasaan pengetahuan peserta didik sebagai hasil belajar yang pada umumnya hanya ditagih lewat bentuk tes tulis tetapi asesmen otentik tidak demikian. Asesmen otentik memungkinkan dilakukannya pengukuran secara langsung terhadap kinerja peserta didik sebagai indikator capain kompetensi yang dibelajarkan. Asesmen otentik menuntut peserta didik untuk berunjuk kerja dalam situasi yang konkret dan sekaligus bermakna. Menurut Mueller (2006), asesmen otentik menuntut peserta didik untuk melakukan suatu tugas dunia nyata (real world tasks) dengan mendemonstrasikan penerapan yang bermakna atas pengetahuan dan keterampilan penting. Dengan demikian, asesmen otentik menuntut peserta didik agar dapat menunjukkan hasil belajar berupa kemampuan dalam kehidupan nyata, bukan sesuatu yang dibuat-buat atau yang hanya diperoleh di kelas, tetapi tidak dikenal dalam kehidupan sehari-hari.

Dalam proses pembelajaran, asesmen otentik mampu mengukur, memonitor, dan menilai semua aspek hasil belajar (yang tercakup dalam domain kognitif, afektif, dan psikomotor), baik yang tampak sebagai hasil akhir dari suatu proses pembelajaran, maupun berupa perubahan dan perkembangan aktivitas, dan perolehan belajar selama proses pembelajaran di dalam kelas maupun di luar kelas. Hal ini sejalan dengan pendapat Owen dan Smith (2000), yang menyatakan bahwa penilaian otentik dapat digunakan untuk mengukur proses dan hasil belajar 
peserta didik secara menyeluruh. Callison (2007) juga berpendapat senada, yang menyatakan bahwa asesmen otentik sebagai suatu proses penilaian mencakup berbagai bentuk pengukuran kinerja yang menggambarkan belajar, prestasi, motivasi, dan sikap peserta didik atas aktivitas-aktivitas yang berhubungan dengan pembelajaran.

Asesmen otentik yang didesain dengan baik akan mampu memberikan gambaran yang kaya atas apa yang telah diketahui dan bisa dilakukan peserta didik. Asesmen otentik memajankan proses dan produk belajar, membuat peserta didik sadar terhadap proses belajarnya (Kerka, 1995). Asesmen otentik memberikan kesempatan luas pada peserta didik untuk menunjukkan apa yang telah mereka pelajari selama proses pembelajaran (Johnson, 2002:165).

Asesmen otentik ini ternyata belum banyak yang diterapkan dengan tepat dalam pembelajaran. Berdasarkan hasil riset dan berdasarkan studi pendahuluan yang telah dilakukan, dapat disimpulkan bahwa asesmen otentik belum diterapkan secara maksimal di sekolah-sekolah. Sistem penilaian secara umum belum mampu menggambarkan kemampuan peserta didik secara nyata. Akibat belum diterapkannya asesmen otentik, peserta didik kurang menguasai materi yang sifatnya aplikatif berkaitan dengan dunia nyata. Hal ini dapat dilihat dari fakta dan hasil riset yang telah dilakukan terhadap peserta didik baik secara nasional maupun secara internasional, yang hasilnya belum baik.

Gambaran masih belum maksimalnya pelaksanaan evaluasi pembelajaran di sekolah adalah masih dominannya salah satu jenis alat evaluasi yang digunakan seperti tes tulis. Tes tulis sendiri sebenarnya tidak ada masalah selama yang diukur adalah kemampuan yang sifatnya kognitif atau pengetahuan. Tetapi, tentu tidak semua yang dipelajari peserta didik sifatnya kognitif, tapi juga afektif dan psikomotorik. Khusus dalam pembelajaran bahasa, tentunya mengukur sampai ranah kognitif saja tidak tepat. Bahasa adalah suatu keterampilan. Belajar bahasa apapun tujuan utamanya adalah agar anak terampil berkomunikasi dengan bahasa tersebut. Oleh karena itu, dalam proses pembelajaran maupun evaluasinya mestinya tetap bermuara pada tujuan tersebut, yaitu agar peserta didik dapat berkomunikasi dalam suasana pembelajaran yang menghargai peserta didik sebagai individu.

Salah satu bentuk nyata belum diterapkannya asesmen otentik adalah diselenggarakannya Ujian Nasional (UNAS). UNAS jelas marupakan bentuk penilaian yang tidak sesuai dengan asesmen otentik. UNAS secara umum masih mengukur kemampuan peserta didik sampai dengan ranah kognitif semata. Tapi, bagaimana dengan aspek afektif dan psikomotorik? Begitu pula dalam mengevaluasi pembelajaran bahasa Indonesia. Ujian nasional belum mampu untuk mengevaluasi pembelajaran keterampilan berbahasa seperti menyimak dan berbicara.

Gambaran tentang kondisi evaluasi pembelajaran selama ini juga dapat dilihat dari berbagai hasil penelitian yang dilakukan terhadap peserta didik Indonesia. Hasil penelitian di beberapa bidang termasuk bahasa yang telah dilakukan selama ini terhadap peserta didik Indonesia masih memprihatinkan. Kualitas sumber daya manusia Indonesia yang dilihat dari prestasi peserta didik belum sesuai dengan harapan nasional, apalagi memenuhi standar internasional. Secara internasional, indikator rendahnya sumber daya manusia ini dapat dilihat dari prestasi peserta didik yang merupakan hasil mutu pendidikan nasional. 
Asesmen otentik tepat digunakan untuk mengevaluasi keterampilan berbahasa. Dikatakan demikian karena pendekatan pembelajaran bahasa yang digunakan sekarang ini adalah pendekatan komunikatif, yang arahnya pada kemampuan perserta didik dalam berkomunikasi senyatanya. Belajar bahasa apapun, tujuan utamanya adalah untuk berkomunikasi dengan bahasa tersebut. Oleh karena itu, dalam proses pembelajaran maupun evaluasinya haruslah tetap bermuara pada tujuan tersebut, yaitu agar peserta didik dapat berkomunikasi dalam suasana pembelajaran yang menghargai peserta didik sebagai individu. Hal ini diperkuat dalam Permen No. 22 Tahun 2006 tentang Standar Isi Kurikulum Bahasa Indonesia SMA, bahwa pembelajaran bahasa Indonesia diarahkan untuk meningkatkan kemampuan peserta didik untuk berkomunikasi dalam bahasa Indonesia dengan baik dan benar, baik secara lisan maupun tulis. Mata pelajaran Bahasa Indonesia salah satu tujuaannya adalah agar peserta didik memiliki kemampuan berkomunikasi secara efektif dan efisien sesuai dengan etika yang berlaku, baik secara lisan maupun tulis.

Arah pembelajaran bahasa jelas pada keterampilan berbahasa, bukan pada pengetahuan bahasa. Kenyataannya, yang dievaluasi guru ternyata masih banyak yang sekedar menggali pengetahuan bahasa semata, bukan pada kegiatan berbahasa yang sesungguhnya. Dengan demikian, keterampilan berbahasa nyata seolah-olah lepas dari pembelajaran di sekolah. Melalui asesmen otentik, keterampilan berbahasa akan dapat diukur secara tepat.

Asesmen otentik dalam penelitian ini diterapkan untuk mengukur keterampilan berbahasa Indonesia lisan (mendengarkan dan berbicara). Keterampilan ini dijadikan fokus karena keterampilan berbahasa lisan mendu- duki fungsi yang sangat esensial. Keterampilan berbahasa lisan merupakan prasyarat untuk membangun keterampilan berbahasa tulis. Menurut O'Malley \& Pierce (1996), salah satu tanggung jawab guru bahasa untuk semua tingkatan adalah mengantarkan para peserta didik mampu berkomunikasi berbahasa lisan secara efektif.

Agar penilaian keterampilan berbahasa lisan dapat dilakukan dengan otentik, O'Malley \& Pierce (1996) menyarankan dengan membuat penilaian yang mencerminkan pembelajaran. Penilaian dimulai dengan mengidentifikasi tujuan dan kegiatan pembelajaran yang terfokus pada kegiatan semua keterampilan bahasa lisan yang akan diterapkan dalam kegiatan kelas. Kegiatan di kelas tersebut mestinya bisa menjaring performa peserta didik dengan valid dan bisa penyekoran yang reliabel.

Berkaitan dengan berbagai hal yang telah dibahas, pengembangan asesmen otentik dalam pembelajaran keterampilan berbahasa lisan termasuk di SMA memang menjadi kebutuhan guru dan tuntutan peserta didik saat ini. Dengan dikembangkannya model asesmen otentik ini diharapkan dapat memberikan inspirasi pada guru untuk mengembangkan dan meningkatkan mutu evaluasi pembelajaran keterampilan berbahasa Indonesia agar menjadi lebih baik lagi. Lebih jauh lagi melalui asesmen otentik, guru dapat memanfaatkan pembelajaran untuk mengembangkan potensi peserta didik agar lebih terampil berkomunikasi, memiliki jiwa eksploratif, memiliki jiwa kreatif, dan memiliki semangat integratif. Bekal keterampilan, sikap, dan motivasi inilah yang justru kelak akan berguna bagi peserta didik dalam kehidupannya, bukan hafalan-hafalan kering tanpa makna.

Untuk menghasilkan model asesmen otentik dalam pembelajaran keterampilan berbahasa Indonesia lisan 
di SMA, dilakukan kegiatan sebagai berikut. Pertama, dilakukan kegiatan penyusunan perangkat asesmen otentik dalam keterampilan berbahasa Indonesia lisan di SMA. Kedua, dilakukan ujicoba model yang telah tersusun untuk didapatkan model asesmen otentik yang benar-benar tepat dan efektif.

\section{METODE}

Model pengembangan penelitian ini diadaptasi dari Model Pengembangan R2D2 (Reflective, Recursive Design and Development) Willis dan Model Asesmen Bahasa Lisan O'malley \& Pierce. Model R2D2 menghasilkan tiga langkah pengembangan, yaitu (1) tahap pendefinisian, (2) tahap desain dan pengembangan, dan (3) tahap diseminasi. Model asesmen bahasa lisan O'malley \& Pierce terdiri dari tahapan-tahapan, yang meliputi: mengidentifikasi tujuan asesmen, merencanakan asesmen, mengembangkan rubrik atau prosedur penyekoran, menentukan standar asesmen, melibatkan siswa dalam penilaian diri dan penilaian sejawat, dan memilih kegiatan penilaian dan merekam datadata yang terkumpul. Berdasarkan hasil adaptasi kedua model tersebut, dihasilkan langkah pengembangan sebagai berikut: pembentukan tim kolaboratif, studi pendahuluan (tahap pemfokusan), merencanakan asesmen, mendesain dan mengembangkan produk asesmen, mengadakan uji coba produk, merevisi produk, dan mengadakan kegiatan diseminasi produk.

Langkah-langkah pengembangan selengkapnya adalah sebagai berikut. Pembentukan tim kolaboratif terdiri atas ahli, praktisi dalam hal ini guru, dan siswa. Masalah yang muncul dan langkah-langkah dalam pengembangan dipecahkan melalui konsultasi atau diskusi dengan tim. Studi pendahuluan dilakukan untuk mengumpulkan data awal, yang dilakukan dengan dengan teknik observasi, dokumentasi, angket, dan prates. Pada kegiatan merencanakan asesmen, ditempuh langkah-langkah (1) penentuan SK, KD, dan Indikator, (2) penentuan tugas otentik dan kegiatan asesmen, dan (3) pemetaan jenis dan unsur asesmen otentik. Pada kegiatan mendesain dan mengembangkan produk asesmen, ditempuh langkah-langkah (1) mengembangkan perencanaan pembelajaran, (2) mengembangkan instrumen dan rubrik penilaian, (3) menentukan standar asesmen, dan (4) menentukan cara menyimpulkan nilai akhir. Untuk mengetahui tingkat kelayakan produk yang telah dikembangkan, selanjutnya dilakukan uji pengembangan produk. Uji pengembangan produk dilakukan untuk memperoleh penilaian dan telaah dari ahli, telaah dari praktisi (guru bahasa Indonesia), tanggapan dari siswa, dan juga untuk mengetahui efektivitas produk di lapangan. Berdasarkan hasil uji coba, dilakukan revisi produk. Revisi produk didasarkan pada hasil analisis data uji coba produk yang berasal dari ahli, guru, dan siswa. Melalui serangkaian langkah pengembangan ini diperoleh produk yang memadai, dan selanjutnya produk tersebut disebarkan di sekolah-sekolah untuk diterapkan dalam pembelajaran.

Subjek uji pengembangan produk penelitian ini adalah ahli psikologi pendidikan, ahli teknologi pendidikan, ahli perancang pembelajaran bahasa, ahli evaluasi pembelajaran bahasa, ahli keterampilan berbahasa, serta siswa dan guru Bahasa Indonesia SMA Negeri 01 Malang, SMA Negeri 4 Malang, dan SMA Wahid Hasyim Malang. Tinjauan dari ahli dimaksudkan untuk memperoleh penilaian, saran, dan pendapat terhadap kesesuaian asesmen pada pengguna, validitas rancangan, isi, dan kesesuaian bentuk asesmen yang dikembangkan dalam pembelajaran keterampilan berbahasa Indonesia lisan. Subjek 
uji pengembangan produk yang menjadi representasi pengguna berjumlah 6 orang guru bahasa Indonesia SMA dari tiga sekolah, dan siswa kelas $x$ sejumlah lima kelas dari tiga sekolah. Uji pengembangan produk dimaksudkan untuk memperoleh tanggapan dan penilaian terhadap produk yang dikembangkan. Pada format tersebut, guru dan siswa diminta untuk memberikan tanggapan berkenaan dengan keterterapan, efektivitas, dan kesesuaian asesmen yang dikembangkan.

Data dalam penelitian ini dianalisis dengan dua macam teknik. Pertama, data dianalisis secara kualitatif khususnya untuk data dari hasil dokumentasi, angket analisis kebutuhan, karakteristik siswa, dan hasil observasi. Kedua, data dianalisis secara kuantitatif, khususnya untuk data hasil uji coba ahli, telaah guru, tanggapan siswa yang telah dikumpulkan dianalisis dengan menggunakan metode statistik deskriptif untuk melihat persentase jawaban dari para ahli, guru dan siswa pengguna akhir berkenaan dengan aspek yang ditanyakan. Uji lapangan terhadap produk penelitian dilakukan pada lima kelas dari tiga sekolah. Rancangan yang digunakan dalam uji lapangan adalah quasi eksperimental. Sesuai dengan karakteristik quasi eksperimental, peneliti menggunakan kelompok-kelompok kelas yang telah ada, sehingga randomisasi hanya dilaksanakan pada waktu memilih kelas mana yang dijadikan kelompok eksperimen. Jenis rancangan yang digunakan adalah pre test - post test control group. Sebelum model diterapkan (diberikannya treatment), diadakan kegiatan pretest untuk mengetahui kemampuan awal peserta didik dalam keterampilan berbahasa Indonesia lisan. Selanjutnya dilaksanakan treatment (satu variabel) dengan model asesmen otentik. Di akhir treatment dilakukan pengukuran akhir (posttest). Selisih hasil antara pengukur- an awal dan akhir tersebut diinterpreasikan sebagai akibat pengaruh bekerjanya treatment. Data dianalisis dengan menggunakan teknik analisis uji-t sampel berpasangan.

\section{HASIL DAN PEMBAHASAN}

Sesuai dengan tujuan yang hendak dicapai yaitu mengembangkan model asesmen otentik dalam pembelajaran keterampilan berbahasa Indonesia lisan di SMA, dalam penelitian ini telah dihasilkan seperangkat produk akhir penelitian berupa perangkat asesmen otentik dalam keterampilan berbahasa Indonesia lisan di SMA. Produk ini meliputi tujuh belas perangkat asesmen, yang masing-masing terdiri atas (1) perencanaan asesmen, (2) pemetaan asesmen, (3) instrumen dan rubrik asesmen, (4) standar penilaian, dan (5) kesimpulan nilai.

Hasil pengembangan yang dipaparkan dalam penelitian ini meliputi (1) uji ahli, (2) telaah guru bahasa Indonesia, (3) tanggapan siswa, dan (4) uji lapangan. Berikut ini dipaparkan data pengembangan yang telah dikumpulkan dari kegiatan uji coba produk yang meliputi data uji ahli, data telaah guru, data tanggapan siswa, dan data uji coba lapangan.

\section{Hasil Uji Ahli terhadap Produk yang Dikembangkan}

Uji ahli secara umum dilakukan untuk mengetahui kelayakan produk penelitian yang dikembangkan. Uji ahli dilakukan dengan cara menilai dan menelaah produk. Penilaian terhadap produk pengembangan dilakukan dengan mengonfirmasi ketepatan dan kecermatan model yang dikembangkan sesuai dengan keahlian penguji ahli. Produk penelitian ini dinilai oleh ahli di bidang masing-masing, yaitu (1) ahli psikologi pendidikan, (2) ahli teknologi pendidikan, (3) ahli perancang pembelajaran bahasa, (4) ahli evaluasi pembelajaran ba- 
hasa, dan (5) ahli bahasa Indonesia.

Secara umum hasil uji ahli terhadap produk pengembangan menunjukkan hasil yang sangat memadai. Hasil penilaian keseluruhan ahli terhadap produk model asesmen otentik dalam pembelajaran keterampilan berbahasa Indonesia lisan di SMA adalah sebagai berikut. Dari tujuh belas model asesmen otentik yang dikembangkan, $64.71 \%$ dinilai sangat memadai/sangat baik/sangat tepat, 32.35\% dinilai cukup memadai/cukup baik/cukup tepat, 2.94\% dinilai kurang memadai/kurang baik/kurang tepat, dan tidak ada yang dinilai tidak memadai/tidak baik/tidak tepat.

Tanggapan ahli terhadap produk yang dikembangkan cukup beragam. Menurut ahli psikologi pendidikan, sebagian besar asesmen otentik yang dikembangkan dinilai sangat baik sehingga banyak asesmen yang tidak dikomentari. Ini merupakan kelebihan produk asesmen yang dikembangkan. Ada dua hal saja yang menjadi catatan, yaitu AO 02 dan 06. Pada AO 02 ahli psikologi pendidikan meminta penjelasan untuk jenis asesmen portofolio yang dilakukan. Pada AO 06, ahli psikologi meminta penjelasan tentang aplikasi proyek terkait dengan kompetensi dasarnya. Setelah dicermati dan juga memperhatikan masukan dari ahli psikologi pendidikan, asesmen proyek yang dikembangkan memang terlalu sederhana untuk kompetensi dasar seperti itu. Oleh karena itu, asesmen ini akan direvisi.

Kelebihan produk pengembangan penelitian ini menurut para ahli termasuk ahli teknologi pendidikan adalah pada instrumen dan rubrik asesmen otentik yang dikembangkan. Sebagian besar asesmen yang dikembangkan menurut ahli teknologi pendidikan sudah memadai dan sudah lengkap disertai rubrik. Satu hal yang perlu ditambahkan pada produk ini adalah lembar kerja/tugas untuk siswa. Lembar tugas/ kerja yang dalam hal ini peneliti menyebut dengan tugas otentik memang tidak disertakan langsung pada bagian instrumen dan rubriknya, tetapi dicantumkan pada perencanaan asesmen di bagian awal setiap perangkat asesmen.

Menurut ahli perancang pembelajaran bahasa, perangkat asesmen yang dikembangkan secara umum sudah sangat baik. Beberapa konfirmasi ahli perancang pembelajaran mengarah pada jenis asesmen yang digunakan. Ada beberapa jenis asesmen yang menurut ahli perancang pembelajaran $\mathrm{ku}-$ rang tepat. Setelah dikaji lebih mendalam dan juga memperhatikan masukan dari ahli yang lain, beberapa jenis asesmen diganti. Misalnya asesmen portofolio yang dianggap kurang tepat diganti dengan asesmen diri. Asesmen proyek yang dinilai kurang tepat diganti portofolio dan unjuk kerja. Selain itu dikonfirmasi juga tentang mekanisme asesmen proyek yang digunakan. Dalam suatu kompetensi dasar terdapat dua atau tiga proyek. Bagaimana mekanisme asesmen proyek 1, 2, dan 3? Sebenarnya proyeknya sendiri hanya satu, yang meliputi dua atau tiga indikator. Asesmen 1, 2 , atau 3 merupakan asesmen yang berangkai dari suatu proyek, yang dilakukan siswa mulai mengumpulkan data sampai dengan melaporkan bahkan sampai presentasi. Selain itu, beberapa jenis asesmen dipertanyakan manfaatnya untuk apa. Misalnya ada pertanyaan: pemanfaatan asesmen sejawat dan unjuk kerja? Asesmen sejawat merupakan suatu bentuk kepercayaan yang diberikan pada siswa untuk menilai temannya ketika bercerita. Unjuk kerja untuk menilai siswa ketika menanggapi teman yang bercerita. Asesmen diri untuk apa? Asesmen diri digunakan untuk melengkapi asesmen pertama, dan sebagainya. Beberapa masukan lagi dari ahli perancang pembelajaran bahasa adalah 
perlunya dipertimbangkan pelaksanaan asesmen dari segi jumlah siswa, waktu dan aspek pembelajaran yang lain. Indikator dan tujuan diselaraskan. Masukan ini bagus, dan akan digunakan sebagai dasar dalam perevisian produk.

Menurut ahli evaluasi pembelajaran, secara umum hasil pengembangan produk baik. Landasan konseptual lengkap dan cukup meyakinkan. Produk sudah dapat langsung dipraktikkan di kelas oleh guru, nyaris dengan juklak dan juknisnya. Tetapi pertanyaannya adalah apa peran guru kalau semua sudah dibuatkan lengkap seperti itu? Mengapa bukan model dengan contoh-contoh saja? Pertanyaan seperti ini memang pernah diajukan beberapa ahli. Untuk meyakinkan bahwa produk ini bukanlah barang baku yang seratus persen siap dan tinggal memakai saja, dalam petunjuk penggunaan asesmen otentik ditegaskan antara lain hal-hal sebagai berikut. Sebelum produk ini digunakan, guru diharuskan menyusun/memodifikasi sendiri rancangan pembelajaran sesuai dengan kebutuhan. Asesmen Otentik dilaksanakan menyatu dengan proses pembelajaran. Oleh karena itu, dalam pelaksanaannya perlu disusun terlebih dahulu rancangan pembelajarannya. Selain itu, untuk menimbulkan kreativitas guru, model ini terbuka untuk dikembangkan oleh guru sepanjang apa yang dikembangkan tetap bermuara pada hakikat asesmen otentik. Karena model evaluasi pembelajaran yang dikembangkan ini berbentuk asesmen otentik, maka instrumen yang dikembangkan/disesuaikan harus merupakan instrumen yang menuntut tugas dunia nyata.

Menurut ahli evaluasi pembelajaran bahasa, secara umum asesmen yang dikembangkan sudah cukup memadai. Ada beberapa saja asesmen yang perlu dikaji ketepatannya. Misalnya pada asesmen tertentu apakah tepat?
Setelah dikaji dan didiskusikan dengan tim kolaborasi, beberapa jenis asesmen direvisi. Konsistensi penyekoran yang belum konsiten juga diselaraskan dalam produk ini. Beberapa asesmen portofolio direvisi menjadi asesmen unjuk kerja. Asesmen proyek direvisi menjadi asesmen diri. Khusus pada kebenaran isi pada isi puisi diadakan revisi.

Menurut ahli bahasa, secara umum produk perangkat asesmen yang dikembangkan sudah sesuai dengan keterampilan berbahasa yang hendak diukur/diharapkan. Beberapa catatan ahli berkaitan dengan penggunaan bahasa dalam produk ini dijadikan pedoman dalam direvisi.

\section{Hasil Telaah Guru terhadap Produk yang Dikembangkan}

Produk ini ditelaah oleh praktisi, dalam hal ini dilakukan oleh guru bahasa Indonesia di SMA. Telaah dilakukan oleh guru di tiga sekolah, yaitu guru bahasa Indonesia SMA Negeri 01 Malang, guru bahasa Indonesia SMA Negeri 04 Malang, dan guru SMA Wahid Hasyim Malang. Telaah dilakukan dengan cara mencermati produk, apakah produk yang dikembangkan benar-benar dapat dipahami dan dapat diterapkan dalam pembelajaran bahasa Indonesia di sekolah. Penilaian terhadap produk pengembangan dilakukan dengan mengonfirmasi ketepatan model yang dikembangkan. apakah perangkat asesmen otentik yang dikembangkan dapat diterapkan sebagai alat ukur yang tepat dalam mengevaluasi keterampilan berbahasa Indonesia lisan sesuai dengan SK dan KD yang dimaksud.

Hasil telaah guru secara umum menunjukkan hasil sangat baik, dalam arti produk secara umum sangat mudah diterapkan. Dari tujuh belas model asesmen otentik yang dikembangkan, $70.59 \%$ dinilai sangat mudah diterapkan, 28.43\% dinilai cukup mudah diterapkan,

Pengembangan Model Asesmen Otentik dalam Pembelajaran Keterampilan Berbahasa .... 
0.98\% dinilai kurang mudah diterapkan, dan tidak ada hasil telaah guru yang menunjukkan tidak mudah (sulit) diterapkan. Produk asesmen yang dikembangkan secara umum mudah diterapkan oleh guru. Ini merupakan keunggulan produk ini. Beberapa catatan pada asesmen yang dikembangkan adalah pada tingkat keterterapan asesmen tertentu dalam pembelajaran.

Catatan untuk hasil penilaian yang kurang mudah dipahami/tidak mudah diterapkan adalah sebagai berikut. Pada AO 13 kurang mudah diterapkan, seharusnya anak dibekali dulu dengan tata cara mendukung atau menyanggah pendapat orang lain. Pada AO 16 kurang mudah diterapkan, sebaiknya puisi yang dibahas puisi karya siswa sendiri, yang isinya sesuai dengan apa yang diindra oleh anak-anak.

\section{Hasil Tanggapan Siswa terhadap Pro- duk yang Dikembangkan}

Penerapan produk ini dalam pembelajaran ditanggapi oleh siswa, dalam hal ini ditanggapi oleh siswa di tiga sekolah, yaitu siswa SMA Negeri 01 Malang, siswa SMA Negeri 04 Malang, dan SMA Wahid Hasyim Malang. Telaah dilakukan dengan cara memberikan angket pada siswa setelah diterapkannya model asesmen otentik. Intinya, siswa diminta memberikan tanggapan, apakah pembelajaran dengan menerapkan asesmen otentik tersebut benar-benar efektif dan membuat mereka senang dalam pembelajaran.

Hasil tanggapan siswa terhadap model asesmen otentik secara umum menunjukkan hasil cukup baik, dalam arti mereka menganggap pelaksanaan asesmen otentik cukup efektif dan mereka cukup senang mengikutinya. Siswa memberikan tanggapan dan penilaian yang diklasifikasi kedalam sepuluh kategori. Dari kesepuluh kategori ini, secara umum siswa menanggapi $\mathrm{cu}$ - kup baik model asesmen otentik yang dikembangkan. Mayoritas persentase tanggapan pada masing-masing komponen adalah sebagai berikut: (1) sangat senang $86.49 \%$, (2) cukup senang $74.32 \%$, (3) sangat senang $61.49 \%$, (4) cukup senang 50\%, (5) cukup senang $51.35 \%$, (6) cukup senang $61.49 \%$, (7) cukup senang $70.95 \%$, (8) cukup senang $54.05 \%$, (9) cukup senang $61.49 \%$, (10) cukup senang $59.46 \%$. Ini menunjukkan bahwa model tersebut cukup layak digunakan dalam mengevaluasi pembelajaran keterampilan berbahaa Indonesia lisan di SMA.

\section{Hasil Uji Lapangan}

Uji lapangan terhadap produk penelitian dilakukan pada lima kelas dari tiga sekolah. Rancangan yang digunakan dalam uji lapangan adalah quasi eksperimental. Jenis rancangan yang digunakan adalah pratest - postest control group.

Dari kelima analisis data statistik tersebut, keseluruhannya menunjukkan hasil yang sama, yaitu terdapat perbedaan yang signifikan antara nilai prates dan postes karena $p=0.000$. Dengan demikian dapat disimpulkan bahwa model asesmen otentik yang dikembangkan efektif digunakan dalam mengevaluasi pembelajaran keterampilan berbahasa Indonesia lisan siswa SMA.

\section{Revisi Produk}

Revisi produk dilakukan berdasarkan simpulan yang diperoleh dari kegiatan analisis data uji coba produk. Komentar dan saran dari ahli psikologi pendidikan, ahli teknologi pendidikan, ahli perancang pembelajaran bahasa, ahli evaluasi pembelajaran bahasa, ahli bahasa, guru, dan siswa dijadikan acuan untuk keperluan revisi produk pengembangan. Revisi produk tidak hanya dilakukan pada bagian produk yang dinilai kurang memadai saja, tetapi juga 
pada bagian produk yang dinilai cukup/ sangat memadai tetapi ada saran yang memang membuat produk ini menjadi lebih baik lagi.

Disadari oleh pengembang bahwa produk pengembangan ini selain memiliki kekuatan (keunggulan) juga memiliki kelemahan (kekurangan). Keunggulan produk pengembangan ini adalah sebagai berikut. Pertama, pengembangan ini relevan dengan kebutuhan guru dan siswa saat ini. Guru membutuhkan model penerapan model penilaian berbasis kelas seperti yang dituntut dalam KTSP, yang ini sejalan dengan model asesmen otentik. Siswa sebagai individu sekarang ini dituntut tidak hanya memahami pengetahuan saja, tetapi juga kemampuan lain seperti berkomunikasi, bekerjasama, berpikir kritis, kreatif, dan mandiri, yang ini dapat diperoleh melalui pembelajaran yang menerapkan model asesmen otentik. Kedua, produk pengembangan ini telah dinilai oleh para ahli, guru, dan siswa. Oleh karena itu, keunggulannya sudah teruji. Kritik dan saran terhadap produk pengembangan berdasarkan uji coba telah dianalisis dan dilakukan revisi sehingga produk pengembangan tersebut semakin tepat dan efektif. Selain itu, dari hasil uji coba diperoleh keunggulan/ kelebihan produk sebagai berikut (1) petunjuk penggunaan pada produk asesmen otentik sudah sangat sesuai/baik karena dapat memudahkan guru/pengguna dalam menggunakan produk dan (2) secara umum jenis asemen otetik yang dikembangkan sudah sangat memadai.

Kelemahan yang terdapat pada produk ini adalah belum dilakukannya uji coba pada kelompok siswa level pinggiran atau pedesaan. Uji coba masih terbatas pada sekolah negeri unggul dan swasta dengan akreditasi A. Oleh karena itu, ada kemungkinan produk ini masih memiliki kekurangan jika diterapkan pada siswa di level pinggiran atau pede- saan. Berkaitan dengan hal tersebut, penelitian ini membuka kesempatan pada peneliti lain untuk mengembangkan dan menerapkan model asesmen pada level pinggiran atau pedesaan.

Meskipun hasil uji coba menunjukkan bahwa produk telah dirancang sesuai dengan kebutuhan siswa, namun masih banyak aspek yang perlu dikembangkan. Beberapa saran pengembangan asesmen otentik adalah sebagai berikut (1) karena model asesmen otentik ini belum diujicobakan pada level pinggiran/pedesaan, maka perlu diujicobakan kembali pada tahap implementasi/pelaksanaan pembelajaran di sekolah pada level tersebut untuk mengetahui efektifitas penggunaan model yang lebih sempurna, dan (2) model ini dikembangkan pada tingkat SMA kelas $X$, oleh karena itu masih banyak peluang untuk mengembangkan model ini pada kelas dan level yang berbeda.

\section{SIMPULAN}

Dalam penelitian ini telah dihasilkan seperangkat produk akhir penelitian berupa perangkat asesmen otentik dalam keterampilan berbahasa Indonesia lisan di $S M A$. Produk meliputi tujuh belas perangkat asesmen, yang masing-masing terdiri atas (1) perencanaan asesmen, (b) pemetaan asesmen, (c) instrumen dan rubrik asesmen, (d) standar penilaian, dan (e) kesimpulan nilai.

Produk ini dikembangkan melalui langkah pembentukan tim kolaboratif, studi pendahuluan, merencanakan asesmen, mendesain dan mengembangkan produk asesmen, mengadakan uji coba produk, merevisi produk, dan terakhir mengadakan kegiatan diseminasi produk.

Dari seluruh kegiatan pengembangan tersebut dapat diambil beberapa kesimpulan sebagai berikut. Pertama, berdasarkan hasil uji ahli, secara umum produk yang dikembangkan sudah sa-

Pengembangan Model Asesmen Otentik dalam Pembelajaran Keterampilan Berbahasa .... 
ngat memadai. $64.71 \%$ dinilai sangat memadai, 32.94\% dinilai cukup memadai, dan $2.35 \%$ dinilai kurang memadai.

Kedua, berdasarkan hasil telaah guru, produk yang dikembangkan secara umum menunjukkan hasil sangat baik, dalam arti produk secara umum sangat mudah diterapkan. Pada produk Perangkat Asesmen Otentik, 70.59\% hasil telaah guru menunjukkan sangat mudah diterapkan, $28.43 \%$ cukup mudah diterapkan, $0.98 \%$ kurang mudah diterapkan.

Ketiga, hasil tanggapan siswa terhadap model asesmen yang diterapkan secara umum menunjukkan hasil cukup baik, dalam arti mereka cukup senang dengan model asesmen tersebut. Dari sepuluh kategori, mayoritas persentase tanggapan pada masing-masing komponen adalah sebagai berikut: (1) sangat senang $86.49 \%$, (2) cukup senang $74.32 \%$, (3) sangat senang $61.49 \%$, (4) cukup senang 50\%, (5) cukup senang $51.35 \%$, (6) cukup senang $61.49 \%$, (7) cukup senang $70.95 \%$, (8) cukup senang $54.05 \%$, (9) cukup senang $61.49 \%$, (10) cukup senang $59.46 \%$,

Keempat, uji coba lapangan melalui panelitian quasi eksperimen menunjukkan hasil yang efektif. Dari kelima analisis data statistik di lima kelas uji coba, keseluruhannya menunjukkan hasil yang sama, yaitu terdapat perbedaan yang signifikan antara nilai prates dan posasesmen karena $p=0.000$. Dengan demikian dapat disimpulkan bahwa model asesmen otentik yang dikembangkan efektif digunakan dalam mengevaluasi pembelajaran keterampilan berbahasa Indonesia lisan siswa SMA.

Kelima, revisi produk dilakukan berdasarkan simpulan yang diperoleh dari kegiatan analisis data uji coba produk. Komentar dan saran dari ahli psikologi pendidikan, ahli teknologi pendidikan, ahli perancang pembelajaran bahasa, ahli evaluasi pembelajaran bahasa, ahli bahasa, guru, dan siswa dijadikan acuan untuk keperluan revisi produk pengembangan. Revisi produk tidak hanya dilakukan pada bagian produk yang dinilai kurang memadai saja, tetapi juga pada bagian produk yang dinilai cukup/sangat memadai tetapi ada saran yang memang membuat produk ini menjadi lebih baik lagi.

\section{UCAPAN TERIMA KASIH}

Artikel ini diangkat dari laporan hasil penelitian yang dibiayai oleh Dana Hibah Disertasi Program Pascasarjana UM Tahun 2009. Oleh karena itu, ucapan terima kasih disampaikan kepada Promotor, Ko-Pormotor, Penguji Disertasi dan Bapak/Ibu Dosen Pascasarjana Universitas Negeri Malang. Selanjutnya ucapan terima kasih disampaikan kepada dua reviewer anonim yang telah membaca, mengoreksi dan memberi masukan terhadap artikel ini.

\section{DAFTAR PUSTAKA}

Callison, Daniel. 2007. Authentic Assessment. Chicago: American Library Association.

Depdiknas. 2006c. Peraturan Menteri Penididikan Nasional Nomor 22 Tahun 2006 tentang Standar Isi Satuan Pendidikan Dasar dan Menengah. Jakarta: Depdiknas.

Johson, Elaine B. 2002. Contextual Teaching and Learning; What it is and why it's here to stay. United States: Corwin Press, Inc.

Kerka, Sandra. 1995. Techniques for Authentic Assessment, (Online), (www.eric.ed.gov/sitemap/html0900000b8013fc08.html, diakses tanggal 10 Mei 2003).

Mueller, Jon. 2006. What is Authentic Assessment?, (Online), (http://jonathan.mueller.faculty.noctrl.edu/ toolbox/whatisit.htm, diakses tanggal 4 Maret 2007). 
O’Malley, J. Michael \& Pierce, Lorraine Valdez. 1996. Authentic Assesment for English Language Learners. New York: Addison - Wesley Publishing Company.
Owens, Thomas \& Smith, Albert J. 2000. Definition and Key Element of Contextual Teaching and Learning. Washington: Consurtium for Cons. 